\title{
THE FIGHT FOR LAND, WATER AND DIGNITY IN LINDSEY COLLEN'S THE MALARIA MAN AND HER NEIGHBOURS
}

\author{
Felicity Hand \\ Universitat Autònoma de Barcelona
}

\begin{abstract}
The novels of South-African born Mauritian writer and activist Lindsey Collen expose a historical continuum of class exploitation, ranging from the slave past of the country including both pre-abolition African slavery together with indentured labour from the Indian subcontinent to post-independence sweat-shop toil, ill-paid domestic labour and exploited agricultural workers. Her latest novel to date, The Malaria Man and Her Neighbours (2010) probes this continuing class conflict and queries mainstream notions of heteronormativity. Access to water and land will be seen to lie behind the murder of the four main characters and the subsequent popular reaction. Collen insists that the underprivileged can become empowered through union, that participation and joint, communal effort can still make a difference.
\end{abstract}

Keywords: Mauritius, Lindsey Collen, Class Conflict, History, Uprising.

LA LUCHA POR LA TIERRA, EL AGUA Y LA DIGNIDAD EN

THE MALARIA MAN AND HER NEIGHBOURS DE LINDSEY COLLEN

\section{RESUMEN}

Las novelas de la escritora y activista mauriciana de origen sudafricano, Lindsey Collen, denuncian un continuo histórico de explotación de clase. Dicha explotación incluye el pasado esclavista del país y, a partir de la abolición de la esclavitud, la contratación de obreros indios y en la época poscolonial el trabajo mal pagado en los talleres textiles, el ámbito doméstico y la agricultura. En su novela más reciente, The Malaria Man and Her Neighbours (2010) Collen sigue explorando este conflicto de clase además de cuestionar la heteronormatividad de la sociedad y demuestra que el libre acceso al agua y a la tierra esconde el motivo del asesinato de los cuatro personajes principales, lo cual da lugar a una rebelión popular. La autora insiste en que los menos privilegiados de la sociedad pueden hacerse fuertes si se unen y que los esfuerzos comunes todavía pueden marcar la diferencia.

Palabras clave: Mauricio, Lindsey Collen, conflictos de clase, historia, rebelión.

DOI: https://doi.org/10.25145/j.recaesin.2021.82.05

Revista Canaria de Estudios Ingleses, 82; April 2021, pp. 63-77; ISSN: e-2530-8335 
South-African-born Mauritian writer Lindsey Collen is the best known English language writer in the country, a former French and British colony, where the bulk of the population speak Kreol, a language based mainly on French with several words incorporated from Malagasy and Tamil. In this article I celebrate Collen's writing with special emphasis on her most recent novel, which showcases the major issue that recurs in her work, namely class conflict. In the first part of the article I locate Mauritius firmly in the wider Indian Ocean arena as none of its inhabitants is a native of the island. The majority of the population came from either Eastern Africa as slaves or the Indian subcontinent as indentured labourers. The Franco-Mauritians hailed from Europe and the Sino-Mauritians from China, which makes the country a perfect example of transoceanic identity. However, I also examine the flip side to what has been called the Mauritian miracle, which is the basis of the work of Lindsey Collen. In the second section I outline the major concerns of her work, which echo her political activism as a member of Lalit -struggle in Kreol- a left-wing party that fights for class equality, environmentalism, women's rights and is adamantly against any kind of communalism. The third part of the article focuses on Collen's latest novel to date The Malaria Man and Her Neighbours (2010). Here Collen returns to her usual battleground of class conflict as this novel could be classified as a blueprint for rebellion in line with her 2001 novel Mutiny. However, this more recent work contains some of the writer's other concerns, namely environmentalism and homo- or transphobia. I conclude by claiming that Lindsey Collen's oeuvre is a true reflection of the hybridity and Indian Oceanness of her adopted country.

\section{MAURITIUS, THE STAR AND KEY OF THE INDIAN OCEAN ${ }^{1}$}

The South-Western Indian Ocean island nation of Mauritius seems to be an example of cosmopolitan multiculturalism. I use the term "island nation" with the utmost caution and merely as a kind of shorthand. The Republic of Mauritius comprises the islands of Rodrigues, Agalega and Saint Brandon (Cargados Carajos) as well as the major island of Mauritius but I will be concentrating on the latter. ${ }^{2}$ In such a small, compact country, covering just under 2,000 square kilometres, isolated geographically from the African continent with even Madagascar 800 kilometres away, ethnic tolerance and democratic space sharing become a necessity of survival. Although Hindus constitute just over half of its almost 1.3 million inhabitants

1 The motto Stella Clavisque Maris Indici features on the official coat of arms.

${ }^{2}$ It is beyond the scope of this article to discuss the Chagos Archipelago, leased by the British to the Americans in the 1960s for the construction of a military base and currently part of the British Indian Ocean Territory. The 2019 United Nations Resolution has - unsuccessfully- demanded the UK return control of the Chagos Islands to Mauritius and thus allow the deported inhabitants to return to their homeland. See Hand \& Pujolràs-Noguer 2019 and Hand 2021 forthcoming. 
and all South Asian groups together make up seventy percent, no community can claim any ancestral rights to the land. All the present inhabitants of the country are by definition uprooted immigrants, the majority descending from slavery or indentured labour.

Accordingly, the land does not "belong" to any of the established communities and the Mauritian constitution has endeavoured to safeguard the rights of the smaller groups by way of its best loser system, using the Block Vote system. ${ }^{3}$ In addition, eight members are appointed from a list of unsuccessful candidates under a "best loser" system designed to provide "balanced" ethnic and political representation. (Bunwaree \& Kasenally 2005: 16), thus ensuring a fluid political representation of all to a greater or lesser degree (Srebrnik $2002 \&$ Cawthr 2005).

Mauritius was heralded as an economic miracle at the turn of the $21^{\text {st }}$ century. Terms such as the "African Tiger" have been applied as a means to explain the causes of the rising economic success of this island state (Aumeerally 2005; Frankel 2010). Until the time of independence, the Mauritian economy was based on its major crop the sugar cane. As sugar prices slumped during the late 1970s there was clearly an urgency to diversify the economy and during the 1980s Mauritius branched out into off-shore banking, and financial sectors started to blossom. This post independent boom led to the establishment of the island as an EPZ (Export Processing Zone) which in turn encouraged new investors to manufacture products using cheap local labour and avoiding cumbersome import and export duties (Curran 36). The success of these ventures has been proved by Mauritius' improved ranking among the nations of SADC (Southern African Development Community) and sociologists and economists tend to agree that the standard of living in Mauritius is one of the highest anywhere in Africa. Not only is its economy a source of admiration among scholars, its relative political stability, unusual in the African continent, is frequently noted by political scientists. Cawthra, (15) points to the fact that of all the countries in the SADC Mauritius is the most culturally and ethnically diverse.

Of all the ethnic communities that have settled on the island, the descendants of the East African and Malagasy slaves, known as Creoles, are the only ones who can make any claim as to being "authentic" Mauritians as they have no cultural allegiance to any other country. The history of Mauritius has often been narrated as an Indian success story that ignores the dehumanising conditions of slavery under which the Afro-Mauritians lost track of their cultural roots, with the individual struggles and cultural specificities of the former slaves swept under the carpet of historical oblivion, or at best, glossed over. Creole memories, either handed down from earlier generations or reconstructed in the present, celebrate the lost mythical ties with the African continent. Ironically, the very people who bequeathed the

3 The National Assembly consists of 70 Seats. 62 members are elected by direct popular vote in multi-member constituencies (20 three-member constituencies on Mauritius and one two-member constituency on the island of Rodrigues) 
country its most representative identity markers, sega dance rhythms and the Kreol language, are still struggling to find themselves a niche in society (Teelock 106).

Pockets of poverty exist all over the country and do indeed cut across any ethnic divide, and, as will be outlined below, class remains the essential divider and has rendered other categories -ethnic, religious, linguistic- as inappropriate and irrelevant for an appreciation of the work of Lindsey Collen unless it is taken on board. Intersectionality is essential for any significant sociocultural analysis and class and ethnicity definitely need to be considered in conjunction in the Mauritian context. Hence my use of the concept clethnicity, the inescapability of poor economic resources being identified rather too closely with ethnic essentialism or, in the words of anthropologist Thomas Eriksen, the social manifestation of the inevitability that "class as such is abstractly unthinkable removed from community" (110, emphasis in original). ${ }^{4}$

\section{MAURITIUS: THE FLIP SIDE}

Collen's wholehearted participation in grass roots politics and her work in Ledikasyon pu Travayer, an adult literacy association which has also published some of her novels, prove her commitment to fighting for the rights of the less privileged members of society, working-class men and women. Her novels are all set in Mauritius and deal with aspects of Mauritian life, but Collen's agenda is much more far-reaching and cannot be sealed within a postcolonial Mauritian paradigm. Her probing of class issues promotes her work onto an entirely different plane from the current trend in cultural -read "ethnic"- differences, making her concerns in tune with the drawbacks of transnational capitalism and worker exploitation, both local or global. Her work reveals the flip side to the Mauritian miracle far away from the five-star luxury hotels, the stylish Caudan waterfront and the hypermarkets which have become sites of access to globalized capitalism, "exceptional until the Eighties, when shopping was tacitly segregated by class and purse" (Khoyratty 73).

The African tiger may have one of the most defendable democracies in the continent but the riots that ensued after the death of the singer Kaya while in police custody in February 1999 only proved that social harmony and ethnic tolerance is skin deep. The figure of Kaya was much more than a singer, he incarnated the hybrid dream, "the inversion of the colonial founding myth of the island" (ChazanGillig 68). Collen's character Melomann, discussed below in the section on The Malaria Man and Her Neighbours, is modelled on Kaya, whose suspicious death provoked unrest verging on outright rebellion similar to that featured in the novel.

Joseph Reginald Topize, popularly known as Kaya, was a highly significant figure on the Mauritian music scene. He had pioneered a style of Mauritian music known as "seggae," a fusion of West Indian reggae and sega, the traditional folk music

\footnotetext{
${ }^{4}$ For a more complete discussion of clethnicity, see Hand 2010.
} 
of the island nation, which had originated amongst the former slave population. His music defied class or ethnic categories and posited a genuine transnational Indian Ocean identity as his music became popular throughout the Mascarene Islands. He was a Rastafarian and made no attempt to hide his lifestyle and habits but above all he was a man of peaceful methods. Most of his songs were in Kreol and he spoke of revolution and rights, which appealed especially to the Creoles, who saw in him a leader and spokesman. ${ }^{5}$

On February 18th 1999 Kaya was arrested under the Dangerous Drugs Act for smoking marijuana, called ganja in Mauritius, following a decriminalization rally, which was organized by the Mouvement Republicain party and attended by many Rastafarians and local musicians. Kaya was held for several days in Alcatraz Police Cells at Line Barracks in Port Louis without, it appears, the possibility of bail. On February $21^{\text {st }}$ he was found dead in his cell and the official verdict was either suicide or accidental death -he had a fractured skull- but neither rang true amongst the Creole population and protests began almost immediately within Kaya's neighbourhood of Roche Bois and quickly spread across the whole of the country.

Kaya's supporters and fans accused the police of brutality, which was officially denied, but emotions were aflame and riots ensued lasting three days during which shops, homes, and churches were burned and looted, causing approximately fifty million US dollars. Several people were killed in the demonstrations including another musician, Berger Agatha, who was shot by the police (Selvon 506-507). In October 2000 the Government released a report on the riots compiled by a judicial commission. The report criticized the previous Government and the police for their handling of the riots; it also criticized some opposition politicians and Creole activists for inciting some of the riots. The police were criticized for holding the musician in a high security area for a minor offence (US Department of State, 2002). I have elaborated on the Kaya riots at some length as they provide the background to two of Collen's novels: Mutiny (2001) and The Malaria Man and Her Neighbours (2010), which both envisage the possibility of an outright class war. Neither actually succeeds but as Collen herself states in the acknowledgements in Mutiny:

The young people of Mauritius, who, during the February 1999 riots over the death in detention of the popular singer, Kaya, forced the gates of the prison at Borstal open, thus show[ed] the possibility of the kind of things already written down, by that time, in early drafts of this novel (Mutiny 343)

As a committed intellectual, Lindsey Collen's work contains a remorseless indictment of contemporary Mauritian and other Western-oriented societies immersed in -from her point of view-a hedonistic bourgeois capitalist consumerism that has lost sight of the commitment to solidarity and universal fraternity.

${ }^{5}$ In one of his songs in English, Free Man, Kaya calls on people to "draw your destiny and it's time now to stand up/ Believe in the gospel of life/ Cause life is the story, will never die." 


\section{LINDSEY COLLEN'S WRITING}

Collen's work reflects a common political purpose expressed through a highly poetical language and self-reflexive narrative techniques. Her creative energy forges new connections and a literary analysis of the metafictional potential of her novels proves them to be vehicles for the reassessment of -if not a direct challenge tosocial, cultural and historical conventions. Collen's work is a scathing commentary on her society and consequently her latest novel uncovers the intricacies of the classethnic-gender smorgasbord of contemporary Mauritian life.

Collen lives in Mauritius and sets her work very carefully and recognisably within a Mauritian context with the use of place names, phrases in Kreol, references to real people and recent or historical cultural events. However, she juggles very neatly with the two readings: a localized Mauritian -and thus Indian Oceanstory with a global transnational postcolonial discourse (Hand, 2011). In Collen's literary world, Mauritius represents the road map for a new world order, a laboratory where the great human experiment somehow sadly went wrong but which can also provide the key to putting things right. In this sense we can read the national motto somewhat ironically as the colony was the key to efficient imperial connections across the Indian Ocean rather than a solution to peaceful cohabitation. Among the many issues that are recurrent in her work is the imperative need to recuperate and come to terms with the slave past of the country and the vindication of the role of the working class in the forging of a democratic state (There is a Tide 1990); the transnational constraints of heteropatriarchy (The Rape of Sita 1993); a condemnation of injustice and the need to give a voice to the dispossessed (Getting Rid OfIt 1997); a call for action and a recipe for productive solidarity (Boy 2005) and her belief in the strength of community as a means to make changes in society (Mutiny 2001 and The Malaria Man and Her Neighbours 2010).

I place Collen's often mordant criticisms of the workings of her country of adoption within their sociocultural milieu, which does not deny the artistic value of her novels. Her work is not only valid as a kind of political manifesto or as a piece of ethnographic writing. On the contrary, much of the energy that emanates from her work is a result of the combination of the immediacy of her dialogues and the passionate beauty of her language. It is true that Mauritius, and by extension Mauritian literature, does not figure on the mental maps of most post-colonial critics. The almost ambiguous geography of the country - politically part of the African continent but culturally and demographically nodding towards Asia- has not contributed to its inclusion on university reading lists and Collen's work has not featured largely in current postcolonial scholarship. ${ }^{6}$ Undoubtedly, her forceful, almost blunt, didactic social message may have discouraged a certain type of critic,

${ }^{6}$ Recently more critics have analysed Collen's work, for example Githire (2014), Perrin (2014) Matteau Matsha (2015) and Lavery (2016) apart from my own work, Hand (2010; 2011 \& 2020). 
more attuned to gender or ethnic identity politics rather than, what may seem to be, old-fashioned class differences. In a country like Mauritius, whose inhabitants pay allegiance to a diversity of ethnic backgrounds, it takes a dedicated writer to pursue what she feels to be the great social divider: class.

Collen's characters are never identified on ethnic terms, on the contrary, she deliberately con/fuses the issue. Her characters are divided -if at all because Collen believes in the unity of all humankind-along class lines, that is in terms of those who possess jobs, homes, a means to earn a dignified living as opposed to those who are or have been dispossessed of any kind of subsistence, exploited by bosses or simply relegated to the economic periphery of society without a fair chance to improve their status. She alludes intentionally to farmers, fisherfolk and domestic workers as she feels that most middle-class Mauritian writers still have great emotional difficulty in dealing with working people. Contemporary Mauritian writing -in all languagesclearly cannot be contemplated without a reference to the work of Lindsey Collen. ${ }^{7}$

Collen's purpose is to question the validity of Mauritian democracy, especially as regards the less favoured classes in economic terms and those who are discriminated against on account of their sexual orientation or their gender. Her picture of Mauritius differs enormously from the official story, the one proudly announced to the media or even the one political scientists and economists publish their articles on. Her novels paint a completely opposing picture to the official government policy of projecting an image of Mauritians as a peaceful, tolerant people. Tourism accounting for a sizeable chunk of the country's economy, this commonsense approach has been adopted to encourage a growth in the industry. Collen's oeuvre is also transnational as it delves into those issues that disregard national or maritime boundaries and unites people in its bid for a universal post-ethnic, classless and gender-free humanity.

Collen's artistry consists in correctly gauging the exact dose of political accusation and emotional rhetoric, without falling into an excessive propagandistic trap. Her purpose is not to celebrate a successfully planned and adroitly executed prison escape in Mutiny or to chart the road map for a successful popular rebellion in The Malaria Man and Her Neighbours but to draw our attention to the importance of collaboration, mutual aid and, above all, determination. Similar sentiments are echoed in Nawal El Saadawi's prison memoir, when even smuggling out a letter requires a mixture of tenacity and obstinacy:

'Fathiyya, I want to send a letter to my family ... is that possible?'

'Everything is possible,' she whispered.

'Inside prison?' I said out loud, in astonishment.

She laughed. 'Inside prison is just like outside prison. Everything is possible ... what's important is the determination to do it'. (El Saadawi 1994: 135; emphasis mine)

Admittedly, Julia Waters focuses on Francophone literature in her recent study on the Mauritian novel but relegating such a prolific writer as Collen to a mere footnote (2018: 44) seems somewhat amiss. 
Collen exposes a historical continuum of class exploitation in her writing, ranging from the slave past of the country including both pre-abolition African slavery together with indentured labour from the Indian subcontinent to postindependence sweat-shop toil, ill-paid domestic labour and exploited agricultural workers. She argues that "we are split asunder socially into warring groups or classes - those who work to live and those who control stocks derived from past work, work or not" ("The World" 45-46; italics in original) The Malaria Man and Her Neighbours (2010) probes this continuing class conflict and queries mainstream notions of heteronormativity -hence the title, her neighbours, instead of the expected his. In the following section I trace the causes that lead to the deaths of the four main characters, Brij Kalapen, Eshan Zukahi, Melomann and Zan Pol Kanzy/Polet and, more importantly, the uprising galvanized by these murders. Access to water and land will be seen to lie behind the conflict that sets off the tragedy and the subsequent popular reaction. Collen insists that the underprivileged can become empowered through union, that participation and joint, communal effort can make a difference.

\section{THE MALARIA MAN AND HER NEIGHBOURS}

Lindsey Collen's latest novel to date, The Malaria Man and Her Neighbours (2010) relates the events leading up to the suspicious deaths of four working-class characters, whose only crime is to demand the right to live dignified lives. The novel begins with their murders or, according to the police, their deaths by natural causes, suicide, accidental drowning and electrocution (The Malaria Man 12-13). ${ }^{8}$ The subsequent chapters are a flashback of the events that set the rebellion in motion and the final two sections (193-251) provide alternative narratives that fill in the gaps and reflect on the events. In her depiction of the four main characters -or rather the heroes as they will become by the end of the novel-Collen surpasses herself as she creates a trans woman, the malaria man of the title, known as Zan Pol Kanzy or Polet; Melomann, a saxophone player, clearly inspired by Kaya; Eshan Zukahi, a potato planter; and Brij Kalapen, fisherman, pig-breeder and trade union representative for the abattoir where he works. In this novel she abandons her usual trinity of characters who represent the three major ethnic groups of Mauritius: Hindus, Muslims and Creoles, to incorporate Zan Pol, a trans woman and thus to extend the cast of misunderstood, marginalized people. Collen is clearly a political writer and her work may be understood to be too confrontational but she believes, following Jean Paul Sartre, that "the 'engaged' writer knows that words are action" (23).

In her analysis of Mutiny Helen Cousins suggests that "[ $t]$ he sharing of recipes also binds the women together as family" (77). This notion of a family -what I have called a newly constructed clethnic community (Hand 2010: 129)- is a clear case

\footnotetext{
${ }^{8}$ Henceforth all references to the novel will be cited as MM followed by the page numbers. As Collen uses italics a great deal, unless otherwise stated, they are hers.
} 
of practical identity taking over from categorical identity. The four protagonists of The Malaria Man and Her Neighbours make up Zan Pol's family and this clethnic community of four who give their name to the riots (MM 232) embody the hybrid mixture of Mauritian society, in both ethnic and gender terms. Brij, the Hindu, works as a pig farmer in an abattoir; Eshan Zukahi, the Muslim convert (MM 59), plants potatoes at the co-op farm; Melomann and Zan Pol/ Polet, from the Creole community, work as malaria men cleaning canals and rivers of mosquitoes. Collen's creation of a trans woman who is disowned by her family and the victim of regular taunts and even assault widens the group of discriminated individuals, as fluid gender identities clash against the intolerance of prejudiced societies. Zan Pol is forced out of her home after it is hit by a cyclone and her homeless state makes her an easy prey for transphobic abuse:

So then she became a refugee. Housed in the social centre. She had to cower there, for weeks. Because of a bunch of youths who would hang around and goad her. Until she ended up in hospital so badly injured (MM 53).

Zan Pol's life is circumscribed by her gender identity. In moments of panic, as when Eshan discovers who is behind the diversion of the water and redirects the flow to its original path, Collen plays with personal pronouns to indicate the performativity of gender as the malaria man fluctuates his/her identity according to the situation. "Zan Pol nearly faints in fright. He lets go his bicycle, he becoming she and back to he again, his her and back his again" (MM 134). Zan Pol demonstrates the inadequacy of stereotypical qualities based on outmoded gender binaries. The typical attribution of bravery to men is dismantled by Collen when Zan Pol is "suddenly terrified by what Eshan has done. His courage wanes. I am not brave enough for this, whether I'm him or her" (MM 134). Biological reductionism together with the binary of nature and culture are dismissed by Collen who gives a voice to the trans community through this sometimes flamboyant but always warm and affectionate character, much loved by her working-class neighbours. Eshan takes a basket of mangoes to his fellow malaria men but Zan Pol deserves an extra portion:

One share as Melomann's workmate, one as their neighbour. Once a neighbour always neighbour. She used to live in the rented house just next door [...] [t]hen there was a Cyclone that blew it all away (MM 53).

The reference to cyclones is common in Mauritian writing and Lindsey Collen's work is no exception.' She uses the cyclone as a metaphor for class as, although it destroys implacably without selecting its victims, its effects depend very much on their economic situation (Hand 2010: 58 \& 122). While The Malaria Man and Her Neighbours does not focus specifically on this meteorological phenomenon, so common in the South-West Indian Ocean, the passing reference cannot go unnoticed

\footnotetext{
9 See Hand (2020) and Ravi (2017) for further discussion on cyclones in Mauritian writing.
} 
as a feature that ravages the poor and vulnerable members of society. Class conflict lies at the heart of this novel as the four protagonists -some deliberately, others as collateral damage- are conveniently removed as they challenge the power of what Collen calls finance capital, which, she argues "is in open war-fare against the rest of the globe and against its people" (webpage 2019).

Mal Benny, the general manager at the abattoir, suspected of double-dealing with local mafias and bent on privatising the business, has no sympathy for Brij or his fellow union delegates. He aims to cut short their complaints by patronising them and undercutting their class loyalties:

Each person in this country-including you three misfits-is no more than a member of a particular group, a community, a race, a religion [...] and that is where you fit. In your community. Which is why you are misfits. [...] Creoles where they belong, in pork. Muslims in their rightful place, beef, Hindus, since there are neither vegetables nor salads in here, in goats (MM 120).

Mal Benny -far from being blessed ${ }^{10}$ with positive attributes- is an unpleasant, despicable boss determined to eliminate the troublemakers who have uncovered his devious business plans. The action that triggers the deaths of the four protagonists is Eshan's discovery of why the water supply has been cut off and his crops are dying. The sugar estate bosses intend to drive the small farmers off the land so they can buy it up cheaply and make a huge profit. So determined are they to drive what they call "scavengers off the land ... the hard way" (MM 82) that even rivals team up in order to "eradicate vegetable planters, first divert their water, then get at their land, eradicate the weak" (MM 83).

Ownership of the water supply becomes the key battleground in environmental conflicts around the globe. Lindsey Collen has incorporated ecocritical concerns in her work, for example in Boy where the main character discovers the geography of the island as he learns about the evolution of the country from a slaveowning society to a democracy (The Subversion 156-157), and in There is a Tide and Getting Rid Of It, where, in her own words, the characters are "fractured socially from an exploiting, dominating, warring class" (2019: 47). The Malaria Man and Her Neighbours therefore is a continuation of this concern coupled with the author's belief in the power of solidarity and the need to join forces. As far as environmental movements are concerned, the 1973 Chipko movement in India has inspired popular movements all over the developing world as local communities have joined forces to defend their right to use and control natural resources such as local water supplies, which often involves entering into disputes with multinational corporations and their regional representatives. As Guha and Martínez-Alier suggest, these disputes represent "a new kind of class conflict" (5) because low-income workers find themselves in opposition to economically and politically powerful elites, the local

${ }^{10}$ Perrin points out the pun in this character's name (2014: 75). 
factory manager having morphed into a faceless exploiter from overseas. Likewise, in her book Making Peace with the Earth, Indian activist Vandana Shiva argues that:

Land, for most people in the world, is people's identity; it is the ground of culture and economy. Seventy-five per cent of people in the third world live on the land and are supported by it -the earth is the biggest employer on the planet (30)

In Collen's novel, the murder of the four protagonists is due to their demand for the right to the land and access to the water supply to irrigate it. Shiva goes on to claim that " 'Privatisation' was launched as the core of the globalisation and trade liberalisation paradigm, based on the crude ideology that public is bad, private is good; domestic is bad, multinational is good" (84). Certainly, the bourgeois conspiracy in Collen's novel that threatens the livelihood of many cooperatives has not counted on the fortitude and perseverance of the underclass, steadfast in their convictions. The four so-called troublemakers have to be dealt with conclusively. Melomann, the saxophonist inspired by the seggae musician Kaya, who "sees the class war seeping out of the workplace into everyday life" (MM 92) is arrested for a road accident and found hanging in the police cells. Eshan Zukahi can no longer fight for the co-op land as he very conveniently drowns himself in a well. Brij Kalapen is electrocuted by an obsolete machine used to kill the animals, thus embodying the excuse to privatize the abattoir. Zan Pol/ Polet's death, "tuberculosis, they say, for that transvestite, the Malaria Man, no sign of injury on her body. No autopsy necessary" (MM 154) ignites the mass hysteria that culminates in a fullscale rebellion with barricades, arson and storming of the prisons. Collen provides three narratives of how the rebellion was forged and how it failed to overturn the status quo: Hank, the waterworks technician, who finds himself caught up in the riots; Brij's widow, Binndu's story, in which she inadvertently overhears the plan to do away with the four meddlesome workers; and the omniscient narrator's view of the events. The latter seems to be Collen's final word on rebellions, echoing Mutiny, in which she states that "[i]t's the possibility that's important" (55).

And, of course, it's doomed. Once you win against the police, then what? Nothing is ready to be born. So the vacuum brings looters. Looters bring pillage. Pillage exactions. Then defeat. And they call the whole caboodle 'riots'.

But, and this is the important bit now: It doesn't mean you shouldn't have done it. It just means they chose the time.

This time (MM 188; bold in original)

\section{CONCLUSION. CONSOLIDATING INDIAN OCEAN WRITING}

Environmental concerns hit Mauritius very keenly on $6^{\text {th }}$ August 2020 when the Japanese cargo ship Wakashio ran aground on a coral reef near Mahebourg, in the south east of the island. The resulting oil spill is an ecological tragedy as the consequences on local marine fauna may take years to heal. Mauritian people rallied 
around immediately and worked day and night to contain as much oil as possible so that it wouldn't reach the shoreline, where it is more difficult to clean. The social impacts have been enormous for the fishing communities living in the region because the fish that have been caught contain high levels of arsenic (Lalit 2020; Lewis 2020). This unfortunate incident has served to remind people of the value of nature and the sea in particular. Collen has poignantly expressed her relationship with the sea:

Behind and below the illusion of the stereotypical welcoming and beautiful Indian Ocean and its islands, [...] there is the deep surface of historical lived experiences involving those same waters, filled with diasporic and displaced pain extending back over years (Matteau Matsha \& Stiebel 6; and see Collen's own text in this volume).

Collen's writing is anchored in Mauritian reality and any analysis of her work needs to locate it within the spatial and political geography of the South-West Indian Ocean. Her strong political commitment to stirring social awareness among those people who have been silenced by history or by cultural and gender constraints is one of her contributions to Indian Ocean literature. The interface between the local and global is one of Collen's strengths as her work reaches out beyond the shores of Mauritius to the outside world while at the same time dealing with specificities that characterize the creolized society of the South West Indian Ocean.

For Collen there is plenty of conscience raising still to be done and a need for people willing to add their grain of sand. It is a call for people to become involved and be active players in the tragicomedy of life. Collen speaks to a world-wide readership as she believes it is the global community that has the power to unite and make change matter (2019). In this sense writers - especially in Africa- will always be more than just writers. The tragic career of people like Ken Saro-Wiwa is an inspiring example for many. ${ }^{11}$ George Orwell wrote in 1946 that "In our age there is no such thing as 'keeping out of politics'. All issues are political issues" (Orwell 357) and for Lindsey Collen that lesson has not lost its relevance to 21st century Mauritius and her two novels of rebellion, Mutiny and The Malaria Man and Her Neighbours, can be read as a useful tool for reminding us of the power of solidarity.

The recent oil spill and the fictional events portrayed in Collen's latest novel are no laughing matter but as Rachel Matteau Matsha claims, "[l]aughter symbolizes the subversion of power and resistance that accompanied the creation of identity" (11) so ending the novel with the spontaneous hilarity of Brij's widow, Binndu reinforces Collen's message that:

It doesn't sound much to start with, but as our enemies used to say last time round, it was no more than a saxophone player, a midget, a cripple and a pervert, and look to what lengths those enemies had to go in order to halt their challenge, a challenge that hadn't even taken form yet. So, you never know (MM 251).

${ }_{11}$ See Nixon 2011: 5-29. 
The idea of this being even remotely possible is what Collen wishes to transmit through her writing and the solidarity and community spirit shown in the aftermath of the oil spill suggests that perhaps this is not so far away.

Reviews sent to author: $20 / 12 / 2020$

Revised paper accepted for publication: 31/01/2021 


\section{WORKS CITED}

Aumeerally, N.L. “'Tiger in Paradise': Reading Global Mauritius in Shifting Time and Space”, Journal of African Cultural Studies 17/2 (Dec. 2005): 161-180.

Bunwaree, Sheila \& Roukaya Kasenally. "Political Parties and Democracy in Mauritius", EISA Research Report, No. 19 (2005). http://www.eisa.org.za/PDF/rr19.pdf.

Cawthra, Gavin. "Mauritius. An Exemplar of Democracy, Development and Peace for the Southern African Development Community?" Africa Insight. 35/1 (April 2005): 14-19.

Chazan-Gillig, Suzanne. "The Roots of Mauritian Multiculturalism and the Birth of a New Social Contract: Being "Autochtone", Being Creole." Journal of Mauritian Studies, New Series 2/1 (2003): 64-86.

Collen, Lindsey. Mutiny, Bloomsbury, 2001.

Collen, Lindsey. The Malaria Man and Her Neighbours, Ledikasyon pu Travayer, 2010.

Collen, Lindsey. "Lindsey Collen Looks at Ecology in Her Novels", English Studies in Africa 62/1 (2019): 45-49. https://doi.org/10.1080/00138398.2019.1629684.

Collen, Lindsey. “The World in 45 Minutes -seen by LALIT's Lindsey Collen”, 05-02-2019. https://www.lalitmauritius.org/en/newsarticle/2207/the-world-in-45-minutesseen-bylalits-lindsey-collen-english/.

Cousins, Helen. "Banana Rebellion: Food and Power in Lindsey Collen's Mutiny," Kunapipi 28/2 (2006): 73-82.

Curran, Paul. "Sweet Taste of Freedom". The Geography Magazine (March 1988): 33-37.

Eriksen, Thomas. Common Denominators: Ethnicity, Nation-building and Compromise in Mauritius, Berg, 1998.

El Saadawi, Nawal. Memoirs from the Women's Prison. Trans. Marilyn Booth. The University of California Press, 1994.

Figueroa, Robert \& Claudia MILlS. "Environmental Justice," A Companion to Environmental Philosophy. Ed. Dale Jamieson, Blackwell Publishers Ltd, 2001. 426-438.

Frankel, Jeffrey A. "Mauritius: African Success Story," HKS Faculty Research Working Paper Series RWP10-036, John F. Kennedy School of Government, Harvard University, 2010. http:// nrs.harvard.edu/urn-3:HUL.InstRepos:4450110.

Githire, Njeri. Cannibal Writes. Eating Others in Caribbean and Indian Ocean Women's Writing, University of Illinois Press, 2014.

Guha, Ramachandra \& Joan Martínez-Alier. 1997. Varieties of Environmentalism. Essays North and South, Earthscan Publications, 2006.

Hand, Felicity. The Subversion of Class and Gender Roles in the Novels of Lindsey Collen. Edwin Mellen Press, 2010.

Hand, Felicity. "Lindsey Collen: The Courage To Be Parochial," Wasafiri. Special Issue on Indian Ocean Writing. 26/2 (Spring 2011): 41-45.

Hand, Felicity \& Esther Pujolràs-Noguer. "When the Island Was Sold. Memory, Resilience and Survival among the Chagossians”, 2019. https://blogs.uab.cat/whentheislandwassold/. 
Hand, Felicity. "Mapping Indianness in Mauritius." Revolving Around India(s). Alternative Images, Emerging Perspectives. Eds. Juan Ignacio Oliva-Cruz, Antonia Navarro \& Jorge Diego Sánchez, Cambridge Scholars Publishing, 2020. 169-193.

Hand, Felicity. "Island Resilience: Coral Reefs, Military Bases and Superfluous People" 2021 forthcoming.

Khoyratty, Farhad. "The Port-Louis Waterfronts as Virtual Spaces of Travel and Cognitive Maps for Contemporary Mauritians.” Journal of Mauritian Studies Special Issue 1 (2009): 63-77.

LALIT. https://www.lalitmauritius.org/.

LALIT. "Ecological Tragedy Unfurls as Wakashio Spills Crude Oil -Was it Evitable?” https://www. lalitmauritius.org/en/newsarticle/2640/ecological-tragedy-unfurls-as-wakashio-spillscrude-oil-ndash-was-it-evitable/ 9 August 2020.

Lavery, Charne. “The Darker Side of Durban': South African Crime Fiction and Indian Ocean Underworlds." Journal of Southern African Studies 4/3 (2016): 539-550, http://dx.doi.org/ 10.1080/03057070.2016.1177981.

LEwIs, Dyani. "How Mauritius is cleaning up after major oil spill in biodiversity hotspot." Nature, 585/172 (2020). https://doi.org/10.1038/d41586-020-02446-7.

Matteau Matsha. Rachel, "Surfing the Tide: Cross-cultural Indian Ocean Identities in the Work of Lindsey Collen.” Safundi. The Journal of South African and American Studies, 2015. https:// doi.org/10.1080/17533171.2015.1106170.

Matteau Matsha, Rachel \& Lindy Stiebel. "Deep sea writing: recent conversations with Lindsey Collen, writer and activist from Mauritius." Journal of the Indian Ocean Region (2017). https://doi.,org/10.1080/19480881.2017.1355962.

Nixon, Rob. Slow Violence and the Environmentalism of the Poor, Harvard University Press, 2011.

Orwell, George. George Orwell: Essays. Penguin Classics, 2000.

Perrin, Héléna. Le Politique dans les Romans de Lindsey Collen, PhD thesis, Université de la Réunion, 2014.

RAVI, Srilata. "Tropical Cyclones in Mauritian Literature." Tracking the Literature of Tropical Weather. Eds. Anne Collett, Russell McDougall \& Sue Thomas, Palgrave Macmillan, 2017. 25-44.

Sartre, Jean-Paul. "What is Literature?" Trans. Bernard Frechtman, Philosophical Library New York, 1948. https://archive.org/details/whatisliterature030271mbp.

Selvon, Sydney. A Comprehensive History of Mauritius, $2^{\text {nd }}$ edition. Mauritius Printing Specialists, 2005.

Shiva, Vandana. Making Peace with the Earth, Pluto Press, 2013.

SREBrnik, Henry. "'Full of Sound and Fury': Three Decades of Parliamentary Politics in Mauritius." Journal of Southern African Studies 28/2 (June 2002): 277-289.

Teelock, Vijaya. "Breaking the Wall of Silence. Slavery in Mauritian Historiography." Radical History Review 91 (Winter 2005): 104-109.

United States Department of State. U.S. Department of State Country Report on Human Rights Practices 2001 - Mauritius, 4 March 2002. https://www.refworld.org/docid/3c84d9994.html.

Waters, Julia. The Mauritian Novel. Fictions of Belonging. Liverpool University Press, 2018. 
